\title{
CHARACTERISTICS OF NONDEPOLARIZING NEUROMUSCULAR BLOCK: (I) POST-JUNCTIONAL BLOCK BY ALPHA-BUNGAROTOXIN
}

\author{
Chingmuh Lee, Dennis Chen, and Ronald L. Katz
}

Classicaliy, a neuromuscular block characterized by lack of fasciculation, fade of the train-of-four ${ }^{1,2}$ fade of tetanus, post-tetanic facilitation, and antagonism by the de-curarizing agents, is called a "nondepolarizing" block. In view of the current understanding that d-tubocurarine (dTc) and pancuronium are pre-junctionally active, ${ }^{3}$ one wonders whether these characteristics of "nondepolarizing" block may be partially attributable to pre-junctional effects. We therefore searched for signs of a pure post-junctional non-depolarizing block.

Alpha-bungarotoxin ( $\alpha$-BuTX), a polypeptide with a molecular weight of approximately 8,000 , purified from snake venoms, has been known to produce a longlasting nondepolarizing neuromuscular block by "irreversible" binding to the postjunctional acetylcholine receptors ${ }^{4,5,6,7}$ or receptor sites sensitive to d-tubocurarine (dTc) and acetylcholine (Ach) ${ }^{8,9}$ Because of its high affinity and specificity of binding with the Ach receptors, it has been used in tagging, solubilization, extraction, and purification of the Ach receptors from muscle and from the electric organ of eel, ${ }^{8,0,10}$ and in tagging of the Ach receptors in neurones. ${ }^{11}$ When purified, it has no detectable pre-junctional effects, anticholinesterase activity ${ }^{4,6,7}$ or ganglionblocking property in vivo (personal observation). We therefore examined the neuromuscular blocking characteristics of this unique drug in detail.

\section{METHOD}

Twelve healthy cats, 3.2 to 3.8 kilograms in weight, were subjected to acute experiments. Anaesthesia was induced with pentobarbitone $(50 \mathrm{mg} / \mathrm{kg}$ body weight) intraperitoneally. The trachea, one common carotid artery, and one external jugular vein were cannulated. Ventilation was $20 \mathrm{ml} / \mathrm{kg} / \mathrm{breath}$ at a rate of $18 / \mathrm{min}$, controlled with a Harvard pump. Arterial pressure was recorded continuously from the carotid artery. The sciatic nerve was exposed, severed, and stimulated distally with supramaximal square pulses of $0.1 \mathrm{msec}$ duration, delivered via a Grass SIU 5 stimulus isolation unit, from a Grass 888 stimulator. Single stimulus was applied at $0.1 \mathrm{~Hz}$ continuously. Other frequencies were applied as stated below. Tetanic responses were elicited by $50 \mathrm{~Hz}$ trains of stimuli for five seconds. The insertion of the tibialis anterior muscle was mobilized with a small

Chingmuh Lee, M.D., Assistant Professor; Dennis Chen, M.D., Anesthesia Fellow; and Ronald L. Katz, M.D., Professor and Chairman. Department of Anesthesiology (UCLA), Haibor General Hospital Campus, 1000 West Carson Street, Torrance, California 90509.

Supported in part by NIH GRS Grant \#G-1951.

An abstract of part of the work has appeared in Abstracts of Scientific Papers, published during the 1975 Annual Meeting of the American Society of Anesthesiologists (Chicago, October $1975)$, pp. $365-366$. 
piece of bone and attached by heavy silk to a Grass FT10C force-displacement transducer. The sheath surrounding the tendon was incised. The leg was immobilized by securing the knee and the foot on a heavy metal rack. The pre-load which was required for the muscle to produce maximal tension output on stimulation of the nerve was individually determined, and applied. This approximated $40 \mathrm{gm}$.

The force of contraction of the tibialis anterior muscle was recorded on a Beckman type $R$ Dynograph. Oesophageal and muscle temperatures were maintained at $35.5^{\circ}$ to $37^{\circ} \mathrm{C}$ by a warming mattress and a heating lamp. Purified alpha-BuTX (Lot. No. BGT 41-IZ, Miami Serpentarium Laboratory) was used. All drugs were injected intravenously.

\section{Results}

Onset, potency, and time course of neuromuscular block:

The onset of neuromuscular block was gradual. Approximately 10 minutes (5-25 minutes) after a single bolus of $0.2 \mathrm{mg} / \mathrm{kg}$ of alpha-BuTX, the depression in the twitch height became detectable. It was noted in preliminary observations that some cats did not show any sign of block one hour after intravenous injection of a smaller dose of alpha-BuTX, $0.1 \mathrm{mg} / \mathrm{kg}$. Before the onset of block, there was no transient increase in tension output. No fasciculation, rigidity, or hyper-reflexia were observed.

Complete block ensued in all cats after a total dose of 0.175 to $0.3 \mathrm{mg} / \mathrm{kg}$ of alpha-BuTX, with one exception to be described below. Once block began, a persistent although slow progression followed (Figure 1, A). Progress from 25 per cent to 50 per cent of block required 30 to 60 minutes; from 25 per cent to 75 per cent, 75 to 200 minutes.

Progression of neuromuscular block was exceptionally slow in one cat which received $0.2 \mathrm{mg} / \mathrm{kg}$ of alpha-BuTX. The block was 45 per cent, 50 per cent and 70 per cent in 150 minutes, 200 minutes and 24 hours respectively.

Increase in dosage of alpha-BuTX accelerated the progress of the resultant neuromuscular block. One additional cat received $1.5 \mathrm{mg} / \mathrm{kg}$ of alpha-BuTX as a bolus. The block increased from 25 to 75 per cent in 20 minutes.

Thus, exact measurement of dose-response relations was not practical because of variability in response among cats and because of lack of clear-cut endpoints. In general, $0.1 \mathrm{mg} / \mathrm{kg}$ appeared to approximate the threshold dosage while $0.2 \mathrm{mg} / \mathrm{kg}$ of alpha-BuTX completely abolished the twitch response in most cats in 2 to 5 hours.

No recovery was seen in any cat within 8 to 30 hours of observation. Consequently, any given degree of block occurred only once in each cat, and might represent different points in the time course of block in different cats. Detailed characterization of the block which required repeated examination of various parameters was possible only when the progress of block was slow, as was the case when the dosage of alpha-BuTX was in the order of $0.2 \mathrm{mg} / \mathrm{kg}$.

\section{Effect of Stimulus Frequency}

During block, initiation of a train of twitches at any frequency up to $10 \mathrm{~Hz}$ produced only a very slight fade (from the first to the fourth or subsequent twitches, 


\section{a-BuTX}

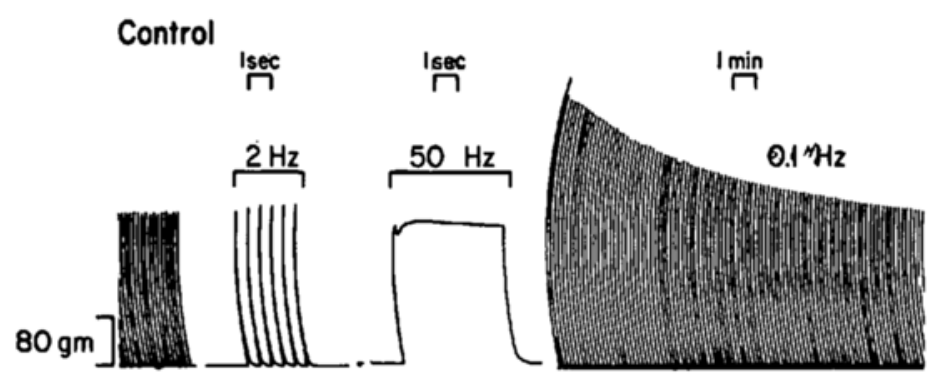

A
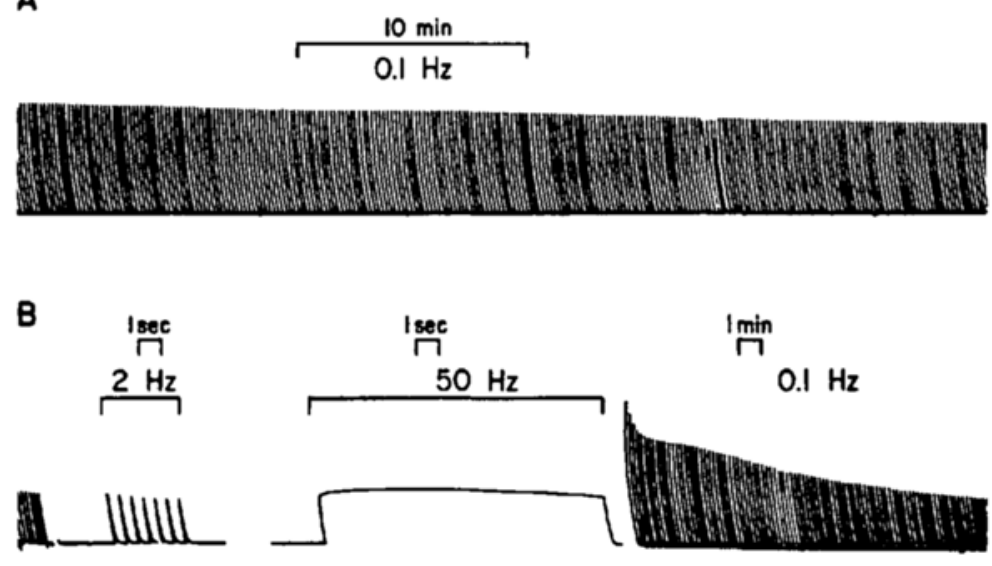

Ficure 1. Neuromuscular block by $\alpha$-BuTX in the cat. Contraction of the tibialis anterior muscle was elicited by sciatic nerve stimulation at $0.1 \mathrm{~Hz}, 2 \mathrm{~Hz}$, or $50 \mathrm{~Hz}$ as indicated. Tetanic contractions by $50 \mathrm{~Hz}$ stimuli were recorded on $1 / 5$ force scale. Paper speed was varied during $2 \mathrm{~Hz}$ and $50 \mathrm{~Hz}$ stimulation, as indicated by time scales. Panel A, obtained 30 minutes after injection of $\alpha$-BuTX, $0.2 \mathrm{mg} / \mathrm{kg}$, demonstrates slow steady progression of the block. Panel B demonstrates lack of fade of train of fast twitches $(2 \mathrm{~Hz})$, sustained tetanus $(50 \mathrm{~Hz})$, and marked post-tetanic facilitation (post-tetanic/pre-tetanic twitch ratio $=2.9$ ) which lasted 12 minutes.

$$
\boldsymbol{a}-\mathrm{BuTX}
$$

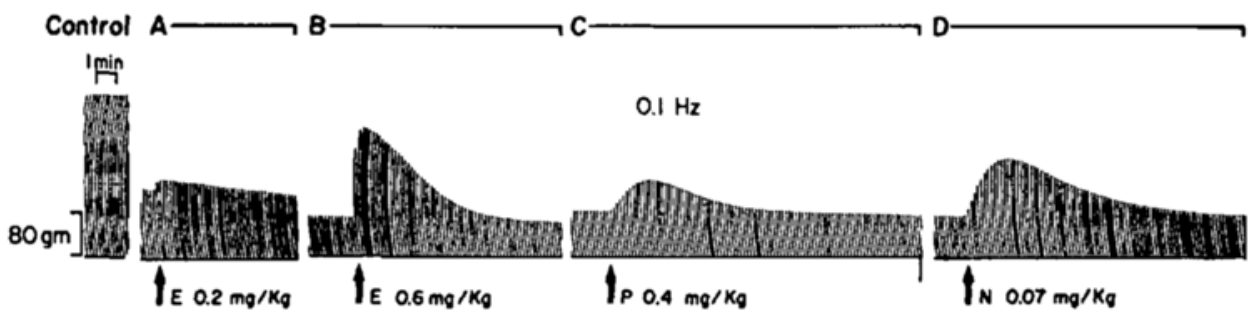

FIGURE 2. Antagonism of $\alpha$-BuTX neuromuscular block by anticholinesterases. Tested from 75 per cent block, edrophonium (E), pyridostigmine $(P)$, and neostigmine $(N)$ in the doses indicated (given at arrows) partially antagonize the block temporarily. Control panel, A, B, C, and $D$, are at least 30 minutes apart. Panel $B$ was not in original sequence. 
twitches from the fourth twitch onwards remaining nearly equal). The fourth-tothe-first twitch ratio, train-of-four ratio, remained near unity (0.85-1.0) (Fig. 1, B). Continuous elicitation of fast twitches (e.g. $1 \mathrm{~Hz}$ ) did not produce a frequencydependent type of block similar to that which can be observed with hemicholinium (HC-3) or triethylcholine, but only accelerated the onset and the progression of block.

\section{Tetanic Contractions}

Partially tetanizing muscle contractions elicited with stimulus frequencies in the range of $5-20 \mathrm{~Hz}$ did not fade. Tetanic contractions elicited with any stimulus frequency $(20-75 \mathrm{~Hz})$ did not fade more than 10 per cent in five seconds at any degree of block in any cat (Figure 1, B).

\section{Post-Tetanic Facilitation}

Post-tetanic twitches were markedly facilitated. The post-tetanic/pre-tetanic twitch ratio was approximately 2.5-3.0/1 immediately (1-2 sec) after a $50 \mathrm{~Hz} 5-$ second tetanus. The facilitation lasted 10-15 minutes (Figure 1, B).

\section{Antagonism of the Block by Anticholinesterase, Succinylcholine and Choline}

Edrophonium, neostigmine and pyridostigmine, given at various degrees of block by alpha-BuTX partially antagonized the block (Figure 2). The antagonism was less effective than the antagonism to dTc-block. The effect was always transient, the progression of the alpha-BuTX block not being arrested, and the slope of the development unaltered. Doses of anticholinesterases normally sufficient to antagonize neuromuscular block produced by dTc completely were only partially effective in antagonism of comparable degree of neuromuscular block produced by alpha-BuTX. Thus, edrophonium chloride $(0.2 \mathrm{mg} / \mathrm{kg})$ neostigmine methylsulfate $(0.07 \mathrm{mg} / \mathrm{kg})$, and pyridostigmine bromide $(0.4 \mathrm{mg} / \mathrm{kg})$ restored a twitch from 40 per cent of control to approximately 50-60 per cent, 50-90 per cent or 60-80 per cent of control respectively (Figure 2 ). The block returned to previous level in 3-10 minutes, 5-15 minutes, and 5-15 minutes respectively.

The depolarizing drugs succinylcholine and choline were also less effective in antagonism of alpha-BuTX-induced neuromuscular block than in antagonism of dTc-induced neuromuscular block. The twitch height restored was less than 10 per cent of control, and the antagonism lasted less than one minute.

Exact quantitation of these effects was similarly impractical because the available observation time was limited, the natural rate of progression of block varied from cat to cat, any given degree of block occurred only once in each cat, and cost did not allow a larger number of experiments.

\section{Side Effects}

Alpa-BuTX in the dose range used produced no cardiac arrhythmia, no changes in the pupil, no incontinence, salivation or vomiting, and no contractures. AlphaBuTX also offered no apparent protection from the cardiac arrhythmia resulting from injection of anticholinesterases in the cat. 


\section{Discussion}

Classical understanding of neuromuscular block was that the depolarizing drugs block neuromuscular transmission by lasting depolarization of the endplate, while the nondepolarizing or competitive drugs block by competition with acetylcholine for the post-junctional receptors thereby preventing normal depolarization. Subsequent investigations have demonstrated that $\mathrm{dTc}$ and many other "nondepolarizing" neuromuscular blocking agents also have pre-junctional effects., ${ }^{32-15}$

Both alpha-BuTX and dTc bind to receptors on the Ach-receptive sites without causing depolarization. The main differences, according to current information, are: (1) alpha-BuTX has little, if any, pre-junctional effects, ${ }^{4,6,7,16}$ (2) alpha-BuTX blocks "irreversibly," or practically permanently, 4,5,17 and (3) alpha-BuTX has no detectable blocking effects on the ganglia or cholinesterases. ${ }^{4,6,7,18}$

Comparison of the characteristics of neuromuscular blocks by $\mathrm{dTc}^{2}$ and by alpha-BuTX in vivo shows the following differences: (1) alpha-BuTX has a considerably slower onset, (2) during partial block by both drugs marked post-tetanic facilitation is seen in the cat, but only dTc-block is characterized by fade of the tetanic contraction, as well as fade of the train-of-four twitches, (3) both blocks are antagonized by anticholinesterases, as well as by depolarizing agents, but alpha-BuTX-induced neuromuscular block is less readily antagonized and the block always resumes its projected progression shortly, and (4) dTc but not alpha-BuTX produces hypotension in the cat. The slow onset of alpha-BuTXinduced neuromuscular block can be explained by slow diffusion of the drug. ${ }^{10}$ The lack of side effects is attributed to its specificity of receptor-binding.

The most characteristic feature of the neuromuscular block produced by alpha$\mathrm{BuTX}$, in contrast to the neuromuscular block produced by $\mathrm{dTc}$, is the absence of tetanic fade and the presence of marked post-tetanic facilitation. Train-of-four also fades only minimally, or not at all. Thus the post-junctional nondepolarizing neuromuscular block is not necessarily characterized by fade. This implies that in vivo fade is not an occult physiological phenomenon which becames detectable when the response is sub-maximal, but rather a consequence of drug effect produced by some neuromuscular blocking agents including d-tubocurarine. Electrophysiological studies have demonstrated a decrease in the quantal release of the transmitter during neuromuscular block by $\mathrm{dTc}$ and pancuronium..$^{3,12-15,19-21}$ Previously, Chang and Lee ${ }^{16}$ observed fade with both cobra neurotoxin and dTc with intracellular recording. Differences in experimental methodology may explain the differences.

Post-tetanic facilitation may also be a pre-junctional phenomenon. ${ }^{3,20-23}$ In agreement with Standaert, ${ }^{24}$ however, we are of the opinion that in cat tibialis anterior muscle it may well be a muscle phenomenon because it can be produced by direct stimulation of the muscle even when the neuromuscular transmission is completely blocked, either post-junctionally by alpha-bungarotoxin, pre-junctionally ${ }^{25}$ by beta-bungarotoxin (personal observations, work in progress), or by d-tubocurarine. ${ }^{24}$

Antagonism of dTc-induced neuromuscular block by anticholinesterases is probably attributable primarily to the inhibition of the cholinesterase activity by these agents, although other mechanisms may also play significant roles. ${ }^{26}$ Increase in 
the number of acetylcholine molecules available as a result of inhibition of the cholinesterase activity, may result in antagonism of the bolck by more than one mechanism. For example, the Ach molecules may compete with dTc for receptors or displace the dTc molecules away from the action sites. ${ }^{27,28}$ Unless the dTc molecules are removed, the block may return when the anticholinesterase activity wears off. It is, however, not very plausible to explain anticholinesterase antagonism of alpha-BuTX-induced neuromuscular block by either competition or displacement. If alpha-BuTX binds the receptor at the same site as Ach does ${ }^{10,11}$ in a practically permanent manner ${ }^{4-17}$ and if the binding is so specific and so tight as to permit use of the alpha-BuTX for isolation and purification of the receptor substance, ${ }^{9,10}$ one would not assume that the additional molecules of Ach made available by inhibition of cholinesterase could activate the alpha-BuTX-bound receptors effectively or displace alpha-BuTX from the receptors. In other words, one assumes that the fraction of unbound receptors ${ }^{29}$ during alpha-BuTX-induced neuromuscular block is not altered by the anticholinesterases. It follows that if the antagonism of neuromuscular block is due to an increase in the number of receptors activated, the additional receptors activated must be normally inaccessible to the transmitter without inhibition of the esterase. Or, the antagonism may depend not on an increase in the number of receptors activated but on an increase in the number (incidence) of receptor activation. Anticholinesterases are known to increase the population and prolong the life span of the transmitter and to cause repetitive firing of the motor nerve terminal as well as the motor endplates, ${ }^{30-36}$ all of which may increase receptor activation without increasing the number of receptors activated. The lack of lasting antagonistic effect of the anticholinesterases is due to the irreversibility of receptor binding by the toxin.

\section{SUMMARY}

The characteristics of neuromuscular block produced by alpha-bungarotoxin, a post-junctionally active polypeptide toxin purified from snake venoms, have been studied in vivo in 12 anaesthetized cats, using the sciatic nerve-tibialis anterior muscle preparation. The onset of the neuromuscular block was slow and without fasciculation. The block was persistently progressive. The time course of the block depended on the dosage. In general, $0.1 \mathrm{mg} / \mathrm{kg}$ of alpha-BuTX appeared to approximate the threshold dosage while $0.2 \mathrm{mg} / \mathrm{kg}$ completely eliminated the twitch response in 2-5 hours. No recovery was observed in 8-30 hours. Larger doses accelerated the progression of the block. During the block, tetanic contractions and train-of-four twitches did not fade. The post-tetanic twitches were markedly facilitated. The block was antagonized by edrophonium, neostigmine, pyridostigmine, and succinylcholine, but the antagonism was less effective and shorter-lasting than that observed on curare-block, and the block always resumed the projected progression. Attempts were made to explain the observed difference between alphaBuTX- and dTc-induced neuromuscular blocks by the practically permanent nature of block and the purely post-junctional site of action of alpha-BuTX. It was concluded that a pure post-junctional block is not characterized by fade, which rather might be a pre-junctional effect of some nondepolarizing neuromuscular blocking agents like d-tubocurarine. 


\section{RÉSUMÉ}

La d-Tubocurarine agit à la fois à l'extrémité du nerf moteur et à la plaque motrice de la fibre musculaire (actions pré et post-synaptique). Le bloc musculaire qu'elle produit se caractérise par une absence de fasciculations, un affaiblissement de la "série de quatre" (train of four), une facilitation post-tétanique et, enfin, ce bloc est renversé par les anti-cholinesterases.

Dans le but de mettre en relation ces différentes caractéristiques avec un mécanisme d'action pré et post-synaptique, nous avons fait l'étude d'un agent dont l'action se limite à la région post-synaptique.

L'alpha-bungarotoxine, une polypeptide extraite de venins de serpents, répond à ce critère en agissant uniquement à la région post-synaptique. Aussi, nous avons précisé les caractéristiques du bloc qu'elle produit in vivo, au moyen de préparation sciatique-tibial antérieur, ceci chez 12 chats anesthésiés.

Le bloc s'installait lentement sans que l'on observe de fasciculations et augmentait d'intensité avec le temps, en fonction de la dose. Une dose de $0.1 \mathrm{mg} / \mathrm{kg}$ était la dose-seuil nécessaire pour obtenir unblocage au moins partiel, alors qu'une dose de $0.2 \mathrm{mg} / \mathrm{kg}$ éliminait complètement la réponse au "twitch" au bout de deux à cinq heures. L'absence de réponse persistait de 8 à 30 heures. Les doses plus importantes accéleraient la vitesse de l'établissement du blocage.

Durant la période du bloc, on n'a pas observé d'affaiblissement des contractions tétaniques et de la "série de quatre." La facilitation post-tétanique était augmentée de façon importante.

L'edrophonium, la neostigmine, la pyridostigmine et la succinylcholine renversent ce bloc mais de façon moins complète et de façon plus courte que lorsqu'il s'agit d'un bloc au curare; le bloc réapparaît toujours pour continuer à progresser.

Nous avons tenté d'expliquer les différences observées par la nature presque permanente du bloc produit et par le fait que l'action est exclusivement postsynaptique. On en conclut qu'un bloc limité à la région post-synaptique ne se caractérise pas par un affaiblissement de la série de quatre, contrairement au bloc de la d-tubocurarine.

\section{ACKNOWLEDGEMENT}

The authors are indebted to Ms. Kathryn Hayes for her secretarial assistance.

\section{REFERENCES}

1. Ali, H.H., Utring, J.E., \& Gray, C. Stimulus frequency in the detection of neuromuscular block in humans. Brit. J. Anaesth. 42: 967 (1970).

2. Lee, C., Barnes, A., \& Katz, R.L. Neuromuscular sensitivity to d-tubocurarine: a comparison of 10 parameters. Brit. J. Anaesth. (In press.)

3. Galindo, A. The role of prejunctional effects in myoneural transmission (Review Article). Anesthesiology 36: 598 (1972).

4. LEE, C.Y. Chemistry and pharmacology of polypeptide toxins in snake venoms. Ann. Rev. Pharmacol. 12: 265 (1972).

5. LeE, C.Y. \& ChanG, C.C. Reversibility of neuromuscular blockade by neurotoxins from elapid and sea snake venoms. J. Formosan Med. Assoc. 71 : 344 (1972).

6. LeE, C.Y. \& Chang, C.C. Modes of actions of purified toxins from elapid venoms on neuromuscular transmission. Mem. Inst. Butantan Simp. Internac. 33(2): 555 (1966).

7. Chang, C.C. \& LEE, C.Y. Isolation of neurotoxins from venom of bungarus multicinctus 
and their modes of neuromuscular blocking action. Arch. Int. Pharmacodyn 144: 241 (1963).

8. Miledi, R. \& Potter, L.T. Acetylcholine receptors in muscle fibers. Nature 233: 599 (1971).

9. O’Brien, R.D., Eldefrawi, M.E., \& Eldefrawi, A.T. Isolation of acetylcholine receptors. Ann. Rev. Pharmacol, 12: 19 (1972).

10. Miledi, R., Molinoff, P., \& PotTer, L.T. Isolation of cholinergic receptor protein of torpedo electric tissue. Nature 229: 554 (1971).

11. Greene, C.L.A., Sytrowski, A.J., Vogel, Z., \& NirenberG, M.W. Alpha-bungarotoxin used as a probe for acetylcholine receptors of cultured neurones. Nature 243: 163 (1973).

12. Gergis, S.D., Dretchen, K.L., Sokol., M.D., \& Long, J.P. The effect of neuromuscular blocking agents on acetylcholine release. Proc. Soc. Exp. Biol. and Med. 138: 693 (1971).

13. Calindo, A. Prejunctional effects of curare: its relative importance. Anesthesiology 34: 289 (1971).

14. Sokoll, M.D., Dretchen, K.L., Gergis, S.D., \& Long, L.P. d-Tubocurarine effects on nerve-terminal and neuromuscular conduction. Anesthesiology 36: 592 (1972).

15. Galindo, A. Curare and pancuronium compared: effects on previously undepressed mammalian myoneural junctions, Science 178: 753 (1972).

16. Chanc, C.C. \& LEE, C.Y. Electrophysiological study of neuromuscular blocking action of cobra neurotoxin. Brit. J. Pharmacol. Chemother. 28: 172 (1966).

17. BERG, D.K. \& HALL, Z.W. Fate of alpha-bungarotoxin bound to acetylcholine receptors of normal and denervated muscle. Science 184: 473 (1974).

18. Chang, C.C. \& Su, M.J. Does alpha-bungarotoxin inhibit motor endplate acetylcholinesterase? Nature 247: 480 (February 15,1974 ).

19. ThiEs, R.E. Neuromuscular depression and the apparent depletion of transmitter in mammalian muscle. J. Neurophysiol. 28: 427 (1965).

20. Hubbard, J.L. Repetitive stimulation at the mammalian neuromuscular junction, and the mobilization of transmitter. J. Physiol. 169: 641 (1963).

21. Wislicki, L. Effects of rate of stimulation and of fatigue on the response to neuromuscular blocking agents. Brit. J. Pharmacol. 13: 138 (1958).

22. GaGe, P.W. \& HubBard, J.L. An investigation of the post-tetanic potentiation of endplate potentials at a mammalian neuromuscular junction. J. Physiol. (London) 184: 353 (1966).

23. Rosenthal, J. Post-tetanic potentiation at the neuromuscular junction of the frog. J. Physiol. (London) 203: 121 (1969).

24. Standaert, F.G. The mechanisms of post-tetanic potentiation in cat soleus and gastrocnemius muscles. J. Gen. Physiol. 47: 987 (1964).

25. Chang, C.C., Chen, T.F., \& LeE, C.Y. Studies of the pre-synaptic effect of beta-bungarotoxin on neuromuscular transmission. J. Pharmacol. Exp. Ther. 184: 339 (1973).

26. KATz, R.L. Neuromuscular effects of d-tubocurarine, edrophonium and neostigmine in man. Anesthesiology 28: 327 (1967).

27. GrAY, T.C. The mechanism of reversal of nondepolarizing relaxants. Proc. Fourth World Congress Anesthesiologists (London, Sept. 1968), Excerpta Medica, pp. 431-436 (1970).

28. Feldman, S.A. \& Trrreld, M.F. A new theory of the termination of action of the muscle relaxants. Proc. Roy. Soc. Med. 63: 692 (1970).

29. WAUD, B.E. \& WAUD, D.R. The relation between the response to "train-of-four" stimulation and receptor occlusion during competitive neuromuscular block. Anesthesiology 37: 413 (1972).

30. EcCles, J.C. \& MACFarLaNe, W.V. Actions of anti-cholinesterases on endplate potential of frog muscle. J. Neurophysiol. 12: 59 (1949).

31. Douglas, W.W. \& Paton, W.D.M. The mechanism of motor endplate depolarization due to a cholinesterase inhibiting drug. J. Physiol. (London) 124: 325 (1954).

32. Rixer, W.F., Roberts, J., Standaent, F.G., \& Fujimori, H. The motor terminal as the primary focus for drug-induced facilitation of neuromuscular transmission. J. Pharmacol. Exp. Ther. 121: 286 (1957)

33. WenNer, G. Antidromic activity in motor nerves and its relation to a generator event in nerve terminals. J. Neurophysiol. 24: 401 (1961).

34. MAsLaND, R.L. \& Wigton, R.D. Nerve activity accompanying fasciculation produced by prostigmine. J. Neurophysiol. 3: 269 (1940).

35. LANGLEY, J.N. \& Kato, T. The physiological action of physostigmine and its action on denervated skeletal muscle. J. Physiol. (London) 49:410 (1915).

36. Magleby, K.L. \& Terrar, D.A. Factors affecting the time course of decay of endplate currents: A possible cooperative action of acetylcholine on receptors at the frog neuromuscular junction. J. Physiol. 244: 467 (1975). 